\title{
Bacteriological Study on Acute Suppurative Diseases in Oral Area : with Reference to Peculiarities of Infectious Hemolytic Streptococci
}

\author{
by \\ Juichi SHIRATSUCHI, ${ }^{*}$ Tadashi IKEDA,* \\ Misao ASANO* and Sadamu MIYAZAKI*
}

\section{Introductory}

Staphylococci pyogenes and streptococci pyogenes are generally acknowledged to be pathogenic bacteria in connection with acute suppurative diseases. However, their bacteriological study in the oral area has been scanty so far and the necessity for detection of these bacteria is made all the more imperative by the recent appearance of so-called antibiotics-fast bacteria. Therefore, the authors have undertaken the following series of experiment on the subject. The sensibility test has also been done on separated bacteria as an aid for bacteriological therapy.

\section{Experiment I: Detection of Infection-bacteria in Acute Suppurative Disease Focus}

\section{Examinees.}

40 examinees were selected from the patients who were treated at Dental Hospital, Nihon University School of Dentistry, with which the authors are associated. Their composition were 29 males and 11 females.

Those patients who had been treated otherwise or their foci had experienced the autolysis were exluded from the selection of possible examinees. The fact whether antibiotics were used for them or not has not been taken into consideration.

2. Method for collection of materials.

Specimens of pus and serum for test purposes were collected by means of injectionneedles. Puncture was effected at a place other than the oral cavity as much as possible. However, when impossible, a spot in the oral cavity to be punctured was rendered antiseptic by dressing with iodine tincture and specimens were obtained therefrom.

3. Separate culture media of bacteria.

Use was made of agar culture medium of horse blood and SLANETZ \& RETTGER medium. In the preparation of these media, bouillon which was made from the horse meat itself was used and the ordinary meat extract available on the market was excluded. Reason for this is that some of oral bacteria flora such as viridans streptococci do not grow well on the media with meat extract. Use of SLANETZ \& RETTGER media is based on the fact that bacterial species such as bacillus fusiformis might be detected by their use.

* 白土寿一, 池田 正, 浅野操, 宮崎 定: Dept. of Bacteriology, Nihon Univ. School of Dentistry (Director: Prof. Juichi SHIRATSUCHI) 
TABLE 1 (a)

Circumstances of Bacteria Detection

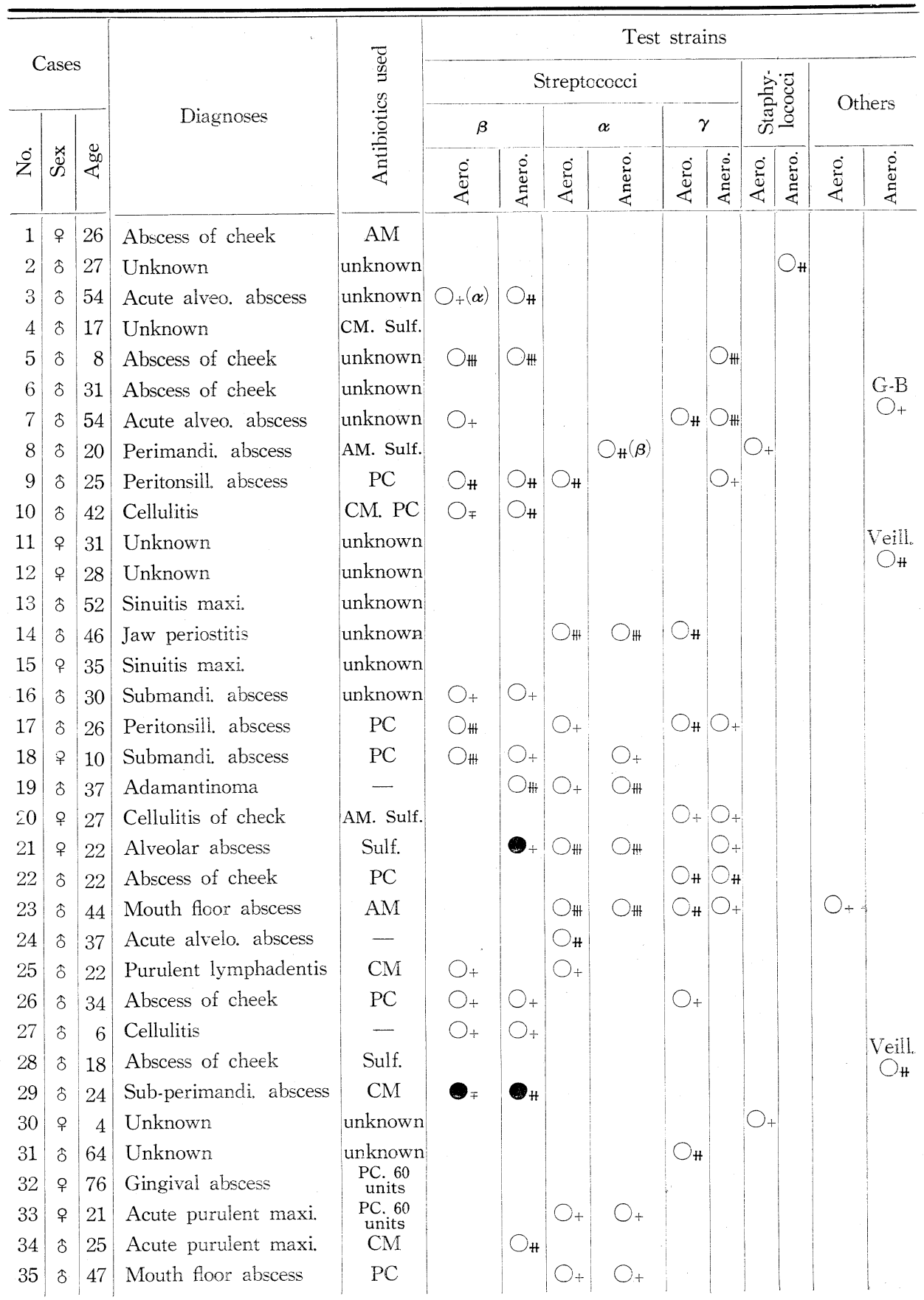


TABLE 1 (b)

\begin{tabular}{|c|c|c|c|c|c|c|c|c|c|c|c|c|c|c|}
\hline \multirow{2}{*}{\multicolumn{3}{|c|}{ Cases }} & \multirow{4}{*}{ Diagnoses } & \multirow{4}{*}{ 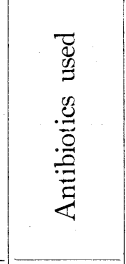 } & \multicolumn{10}{|c|}{ Test strains } \\
\hline & & & & & \multicolumn{6}{|c|}{ Streptococci } & \multirow{2}{*}{\multicolumn{2}{|c|}{ 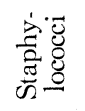 }} & \multirow{2}{*}{\multicolumn{2}{|c|}{ Others }} \\
\hline \multirow[b]{2}{*}{$\dot{2}$} & \multirow[b]{2}{*}{ 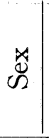 } & \multirow[b]{2}{*}{$\stackrel{8}{<}$} & & & \multicolumn{2}{|c|}{$\beta$} & \multicolumn{2}{|c|}{$\alpha$} & \multicolumn{2}{|c|}{$\gamma$} & & & & \\
\hline & & & & & 造 & $\dot{\grave{d}}$ & 造 & 这 & 这 & $\dot{\stackrel{\dot{U}}{\sharp}}$ & $\stackrel{0}{\dot{2}}$ & $\begin{array}{l}\dot{0} \\
\dot{\bigsqcup} \\
\dot{\Xi}\end{array}$ & 选 & 苞 \\
\hline 36 & q & 44 & Abscess of cheek & - & & & & & & & 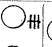 & & & \\
\hline 37 & $\hat{\delta}$ & 7 & Abscess of cheek & $\mathrm{CM}$ & & & & & & & $\mathrm{O}_{+}$ & & & \\
\hline 38 & $\hat{o}$ & 22 & Peritonsill. abscess & $\begin{array}{l}\text { CM. AM. } \\
\text { Sulf. }\end{array}$ & & & & & & & & & & \\
\hline 39 & $\hat{\delta}$ & 54 & Jaw periostits & - & & & & & & & & & G-B & \\
\hline 40 & $\hat{\delta}$ & 29 & Perimaxi. abscess & $\mathrm{CM}$ & $? \bigcirc_{+}$ & & $\mathrm{O}_{+}$ & & $O_{+}$ & & & & & \\
\hline & Note & & $\begin{array}{l}\text { Plus signs indicate } \mathrm{t} \\
\beta \cdots \text { Hemolytic } \\
\alpha \cdots \text { Viridans } \\
\gamma \cdots \text { Nonhemolytic }\end{array}$ & umber of & $\cdots$ & $d m-$ & & 5 & & & & & & \\
\hline
\end{tabular}

\section{Experimental result.}

a. Detection of bacteria.

Kinds of bacterial species which were obtained out of 40 cases subjected to the experiment are given in Table 1.

Of various species found, the cases of streptocccci are as many as 25 (Table 2).

b. Detected species and diseases.

Table 3 gives the names of diseases in which these various bacterial species are detected. It is believed that there does not exist any special relationship between a set of bacteria and that of disease, at least, in regard to the current data.

TABLE 2

Isolated Bacteria from Cases.

I. Streptococci 25 cases

1. Hemolytic streptococci $(\beta)$ 16 cases

(1) $\quad \beta$............................................................... 7 "

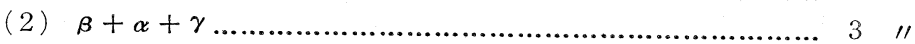

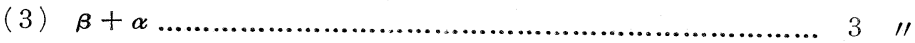

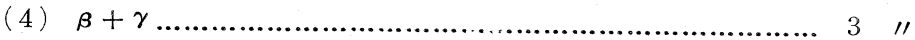

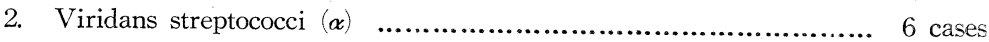
(1) $\alpha$

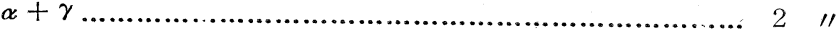

(3) $\alpha+$ staphylococci ............................................. 1 "

3. Nonhemolytic streptccocci $(\gamma)$..................................... 3 cases

II. Staphylococci ............................................. 4 cases

III. Others ................................................... 4 cases

1. Veillonella ............................................................... 2 "

2. Gram-negative bacilli ............................................... 2 "

IV. Non-culture ........................................... 7 cases 
TABLE 3

Isolated Bacteria and Its Diseases

\begin{tabular}{|c|c|c|}
\hline Isolated Bacteria & Cases & Types of diseases \\
\hline 1. Hemolytic streptococci & 16 & * \\
\hline i. $\beta$ & 7 & $\begin{array}{l}\text { alveolar abscess } 1 \text {, ostitis of jaw } 1 \text {. cellulitis } 2 \text {, } \\
\text { abscess of submandibular } 1 \text {, sub-perimandibular } \\
\text { abscess } 1\end{array}$ \\
\hline ii. $\beta+\alpha+\gamma$ & 3 & peritonsillar abscess 2 , periostitis of jaw 1 \\
\hline iii. $\beta+\alpha$ & 3 & $\begin{array}{l}\text { abscess of submandibular } 1 \text {, adamantinoma } 1 \text {, } \\
\text { purulent lymphadentis } 1\end{array}$ \\
\hline iv. $\beta+\gamma$ & 3 & alveolar abscess 1 , abscess of cheek 2 \\
\hline 2. Viridans streptococci & 6 & \\
\hline i. $\alpha$ & 3 & $\begin{array}{l}\text { alveolar abscess } 1 \text {, cellulitis of cheek } 1 \text {, cellulitis of } \\
\text { the floor of mouth } 1\end{array}$ \\
\hline ii. $\quad \alpha+\gamma$ & 2 & periostitis 1 , abscess the floor of mouth 1 \\
\hline iii. $\alpha+$ staphy. & 1 & perimandibular abscess 1 \\
\hline 3. Nonhemolytic streptococci & 3 & abscess of cheek 1 , unknown 1 , ostitis of jaw 1 \\
\hline 4. Staphylococci & 4 & abscess of cheek 2 , unknown 2 \\
\hline 5. Others & 4 & \\
\hline i. Veillonella & 2 & abscess of cheek 1 , unknown 1 \\
\hline ii. Gram-negative bacteria & 2 & abscess of cheek 1, periostitis of jaw 1 \\
\hline
\end{tabular}

\section{Experiment II: Sensibility Test on Antibiotics for Infectious Bacteria}

Most of the examinees who were subjected to these series of experiments had been treated by the use of either antibiotics and antagonizers for the prevention of their diseases from being aggravated prior to coming to our Dental Hospital. As the knowledge on the subject would be of use for post-operative medication, a sensibility test was conducted on the separated bacteria.

\section{Experimental method.}

Exploration paper for sensibility test purpose which was a product of Difco Company was employed in conjunction with the present test. A piece of this paper was applied on the blood agar medium smeared with the separated bacteria and the media were subjected to incubation process for anywhere from 24 hours to 48 hours at $37^{\circ} \mathrm{C}$. The zones inhibiting the growth of bacteria along the periphery of the exploration paper that resulted were measured.

\section{Experimental result.}

Reference is made to Table 4. As regards the figures obtained, chloromycetin rather than penicillin is thought to be more effective with cases No. 18, 23 and 26. A conclusion from this test seems to be that the majority of species show higher sensibility to chloromycetin rather than to penicillin or aureomycin. 
TABLE 4

Sensitivity Test of Isolated Bacteria

\begin{tabular}{|c|c|c|c|c|c|c|c|c|c|c|c|c|}
\hline \multirow[b]{2}{*}{ 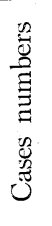 } & \multirow[b]{2}{*}{$\begin{array}{l}\text { Antibiotics } \\
\text { used }\end{array}$} & \multicolumn{2}{|c|}{ Species } & \multicolumn{9}{|c|}{ Diameter of inhibition zone in $\mathrm{mm}$} \\
\hline & & 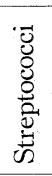 & 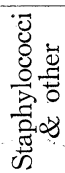 & 葋 & 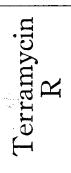 & 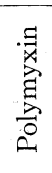 & 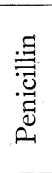 & 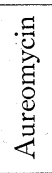 & 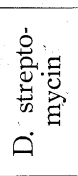 & 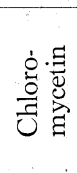 & 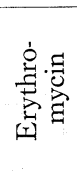 & 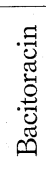 \\
\hline 18 & $\mathrm{PC}$ & $\beta$ & & 19 & & 0 & 14 & 19 & 18 & 34 & & 15 \\
\hline \multirow[t]{2}{*}{19} & - & $\beta$ & & 27 & & 0 & 11 & 26 & 0 & 35 & & 13 \\
\hline & & $\alpha$ & & 20 & & 0 & 0 & 19 & 0 & 28 & & 13 \\
\hline 20 & $\mathrm{AM}$ & $\gamma$ & & 0 & & 0 & 12 & 11 & 0 & 0 & & 10 \\
\hline \multirow[t]{2}{*}{21} & Sulf. & $\beta$ & & 18 & & 0 & 10 & 22 & 15 & 36 & & 13 \\
\hline & & $\alpha$ & & 14 & & 0 & 0 & 18 & 11 & 25 & & 12 \\
\hline 22 & Sulf. & $\gamma$ & & 18 & & 0 & 10 & 23 & 11 & 34 & & 22 \\
\hline 23 & $\mathrm{PC}$ & $\alpha$ & & 16 & & 0 & 13 & 15 & 9 & 24 & & 11 \\
\hline 24 & $\mathrm{AM}$ & $\alpha$ & & 11 & & 0 & 0 & 17 & 18 & 33 & & 13 \\
\hline \multirow[t]{2}{*}{25} & - & $\beta$ & & 14 & & 0 & 8 & 15 & 9 & 28 & & 16 \\
\hline & & $\alpha$ & & 18 & & 0 & 0 & 13 & 8 & 19 & & 12 \\
\hline \multirow[t]{2}{*}{26} & $\mathrm{CM}$ & $\beta$ & & 12 & & 0 & 0 & 19 & 8 & 31 & & 17 \\
\hline & & $\gamma$ & & 31 & & 0 & 11 & 30 & 0 & 34 & & 15 \\
\hline 27 & $\mathrm{PC}$ & $\beta$ & & 1.9 & & 0 & 22 & 18 & 0 & 26 & & 31 \\
\hline 29 & Sulf. & $\beta$ & & 23 & 17 & 0 & 30 & 21 & 18 & 25 & 37 & \\
\hline 30 & $\mathrm{CM}$ & & $\mathrm{s}$ & 23 & 17 & 0 & 30 & 13 & 18 & 19 & 37 & \\
\hline 31 & ? & $\gamma$ & & 13 & 11 & 0 & 26 & 16 & 10 & 23 & 19 & \\
\hline 33 & $\mathrm{PC}$ & $\alpha$ & & 11 & 12 & 0 & 19 & 16 & 9 & 17 & 15 & \\
\hline 35 & $\mathrm{CM}$ & $\alpha$ & & 14 & 15 & 0 & 21 & 18 & 10 & 23 & 25 & \\
\hline 36 & PC & & $\mathrm{s}$ & 16 & 15 & 0 & 0 & 17 & 13 & 16 & 20 & \\
\hline 37 & - & & $\mathrm{s}$ & 16 & 12 & 0 & 0 & 18 & 16 & 19 & 18 & \\
\hline 39 & $\begin{array}{l}\text { CM, AM } \\
\text { Sulf. }\end{array}$ & & * & 17 & 14 & 0 & 33 & 16 & 10 & 23 & 29 & \\
\hline \multirow[t]{2}{*}{40} & $\mathrm{CM}$ & $\beta$ & & 18 & 15 & 0 & 25 & 16 & 16 & 24 & 28 & \\
\hline & & $\alpha$ & & 15 & 13 & 0 & 20 & 15 & 14 & 21 & 25 & \\
\hline
\end{tabular}

* gram-negative bacteria of anaerobic

TABLE 5

Experiment Strains of Streptococci

\begin{tabular}{|c|c|c|c|c|}
\hline Number of strains & \multicolumn{3}{|c|}{ Species (contents of strains) } & Isolation from cases \\
\hline \multirow{3}{*}{158} & 1. & Str. hemolytic & 67 strains & 16 cases \\
\hline & 2. & Str. viridans & $65 \prime \prime$ & $13 \prime \prime$ \\
\hline & 3. & Str. nonhemolytic & $26 \quad \prime \prime$ & $12 \prime \prime$ \\
\hline
\end{tabular}

* Contrast $\cdots$ Human str. pyogenes $\cdots 1$ strain 


\section{Experiment III : Identification of Infectious Bacteria}

Detailed biological observations of the bacterial species detected under Experiment I described above, have enabled us to classify them into three classes of I) streptococci, II) staphylococci, and III) veillonellae.

1. Streptococci.

a. Tested bacterial strains.

158 strains have been subjected to the experiment (See Table 5). With regard to one bacteria species, colonies ranging from 3 to 5 were selected at random.

b. Tested items.

Series of tests covered the following items:

( $i$ ) Classification in terms of biological characteristics.

(ii) Classification in terms of changes appearing on blood agar.

(iii) Benzidine reaction.

(iv) Serological classification.

c. Various results.

(i) Classification in terms of biological characteristics.

SHERMAN's classificatory method has been followed under this test. As is seen from Table 6, 57 strains show a slight degree of trehalose decomposition which makes it difficult to determine whether they are streptococci pyogenes or otherwise. But the authors have regarded them to be similar forms here.

(ii) Classification in terms of changes appearing on blood agar.

SCHOTTMÜLLER in 1903 classified streptococci into those of hemolytic nature and those of viridans nature according to the findings obtained from blcod agar media. Further in 1919, BROWN divided streptococci into three classes of $\beta, \alpha$ and $\gamma$. His $\beta$ class corresponds to hemolytic nature designated by SCHOTTMÜLLER. ANDO carried the study of BROwN much further and established two sub-types (regular $\beta$ type and irregular $\beta$ type) in terms of size of the hemolytic zones clarity of hemolytic boundary and existence of residue blccd corpuscles, etc. He has come to the conclusion that while the former possesses high degree of pathogenicity, the latter entirely lacks it. Table 7 gives a result of a test on hemolytic streptococci in terms of ANDO's classification. 10 strains are found to be of regular $\beta$ type $(\beta \mathrm{t}$ type) and other 57 strains are $\beta \mathrm{m}$ type of irregular $\beta$ type ( $\beta$ at type of $\beta \mathrm{m}$ type and $\beta \mathrm{g}$ type).

Streptococci of $\beta \mathrm{m}$ type which the authors have isolated developed minute colonies following an incubation on the blocd agar media for 24 hours. Some of them formed a hemolytic ring around the colonies, however, the great majority appeared to be $\gamma$ type without showing any hemolysis. After an incubation for 48 hours, however, they came to develop minute colonies which could be obviously determined as such. The average size of a hemolytic ring is $1.0 \mathrm{~mm}$, the large ones ranging from $1.2 \mathrm{~mm}$ to $1.5 \mathrm{~mm}$ in diameter. Under the microscopic observation, they are found to be transparent, smoothly surfaced and have certain gloss, having a slight elevation in the center.

KOBAYASHI carried out a research into an influence of hemolytic streptccocci on globulysis and hematolysis of dextrose in various animal blcods. As a result, he has established the following three types (KOBAYASHI's classification).

Type I. Bacteria of this type prove themselves $\beta$-hemolytic in the blcod agar of the horse, goat or sheep. However, the addition of $1 \%$ glucose produces $\alpha$-hemolytic, $\beta$-hemolytic being inhibited. 
TABLE 6

Biological Characteristics of Streptococci

\begin{tabular}{|c|c|c|c|c|c|c|c|c|c|c|c|c|c|c|c|c|c|}
\hline \multirow{3}{*}{\multicolumn{3}{|c|}{$\begin{array}{r}\text { Division \& } \\
\text { Common } \\
\text { name }\end{array}$}} & \multicolumn{7}{|c|}{ Hemolytic streptococci } & \multicolumn{8}{|c|}{ Viridans streptococci } \\
\hline & & & \multicolumn{3}{|c|}{ Str. pyogenes } & \multicolumn{4}{|c|}{ Similar bacteria } & \multicolumn{4}{|c|}{ Str. mitis } & \multicolumn{4}{|c|}{ Similar bacteria } \\
\hline & & & $\beta$ & $\beta$ & $\beta$ & $\beta$ & $\beta$ & $\beta$ & $\beta$ & $\alpha$ & $\alpha$ & $\alpha$ & $\alpha$ & $\gamma$ & $\gamma$ & $\gamma$ & $\gamma$ \\
\hline $\mathrm{He}$ & & $\begin{array}{l}\text { sistence } \\
0^{\circ} \mathrm{C}\end{array}$ & - & 一 & - & - & - & - & - & - & 一 & - & - & - & 一 & 一 & - \\
\hline \multirow{5}{*}{ 突 } & & $\begin{array}{l}\% \text { bile } \\
\text { M.B. }\end{array}$ & - & 一 & - & - & - & - & - & - & - & - & - & - & - & - & 一 \\
\hline & $\begin{array}{l}6.5 \\
\mathrm{NaC}\end{array}$ & $\begin{array}{l}5 \% \text { bile } \\
\text { I bouil. }\end{array}$ & - & - & - & - & - & - & 一 & - & - & - & - & - & 一 & - & - \\
\hline & & $\begin{array}{l}\text { H } 9.6 \\
\text { bouil. }\end{array}$ & - & 一 & - & - & - & - & - & - & - & 一 & - & - & 一 & - & 一 \\
\hline & $\begin{array}{r}40 \\
\text { blo }\end{array}$ & $\begin{array}{l}\% \text { bile } \\
\text { od agar }\end{array}$ & - & - & - & - & - & - & - & 一 & 一 & 一 & - & - & 一 & 一 & - \\
\hline & $\begin{array}{l}10 \\
\text { blo }\end{array}$ & $\begin{array}{l}\% \text { bile } \\
\text { od agar }\end{array}$ & $\begin{array}{ll}+ & - \\
3 & 2\end{array}$ & \pm & \pm & \pm & \pm & \pm & \pm & $\begin{array}{cc}+ & - \\
28 & 5\end{array}$ & $+\frac{1}{9}$ & $\begin{array}{ll}+5 & - \\
5 & 1 \\
\end{array}$ & $\begin{array}{ll}+7 & \overline{4} \\
7 & 4 \\
\end{array}$ & $\begin{array}{ll}+ & - \\
6 & 4\end{array}$ & + & $\begin{array}{ll}+ & - \\
3 & 2\end{array}$ & - \\
\hline \multicolumn{3}{|c|}{ Final $\mathrm{pH}$} & \multicolumn{3}{|c|}{$4.4 \sim 5.2$} & \multicolumn{4}{|c|}{$4.5 \sim 5.2$} & \multicolumn{4}{|c|}{$4.0 \sim 4.6$} & \multicolumn{4}{|c|}{$4.0 \sim 4.8$} \\
\hline \multirow{2}{*}{\multicolumn{2}{|c|}{$\begin{array}{l}\text { Litmus } \\
\text { milk }\end{array}$}} & Acid & + & + & + & + & + & + & + & + & + & \pm & + & + & + & + & \pm \\
\hline & & Clot & - & - & - & - & - & - & - & $\begin{array}{cc}+ & - \\
15 & 18\end{array}$ & + & - & $+\frac{1}{10}$ & - & - & + & - \\
\hline \multicolumn{3}{|c|}{$\begin{array}{c}\text { Arginine split } \\
\left(\mathrm{NH}_{4}\right)\end{array}$} & + & + & + & + & + & + & + & $\begin{array}{ll}+ & - \\
30 & 3\end{array}$ & $+\frac{1}{6}$ & 一 & - & - & 一 & - & - \\
\hline \multicolumn{3}{|c|}{$\begin{array}{c}\mathrm{NH}_{4} \text { from } \\
\text { peptone }\end{array}$} & + & + & + & + & + & + & + & $\begin{array}{cc}+ & - \\
26 & 7 \\
\end{array}$ & $\begin{array}{ll} \pm & - \\
\end{array}$ & \pm & - & \pm & 一 & 一 & - \\
\hline \multicolumn{3}{|c|}{ Gelatin liquefied } & - & - & - & - & - & - & - & 一 & - & - & - & - & 一 & - & - \\
\hline \multirow{8}{*}{ 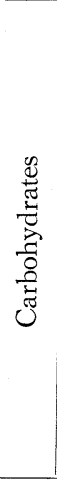 } & & ehalose & + & + & + & - & + & + & - & + & - & + & - & + & + & $\begin{array}{ll}+ & \overline{3} \\
\end{array}$ & - \\
\hline & & orbitol & - & - & - & - & - & - & - & - & - & - & - & - & - & - & - \\
\hline & & annitol & - & - & - & - & - & - & - & - & - & - & - & - & - & - & - \\
\hline & & actose & + & - & + & - & + & - & - & + & + & - & + & + & $\begin{array}{l}+\overline{4} \\
4\end{array}$ & $\begin{array}{ll}+ & - \\
3 & 2 \\
\end{array}$ & - \\
\hline & & ucrose & + & + & + & - & + & + & + & + & + & + & + & + & + & + & + \\
\hline & & affinose & - & - & - & - & - & - & - & - & + & - & - & - & - & -- & - \\
\hline & & alicin & 一 & + & + & - & - & - & - & + & 一 & + & 一 & + & + & $\begin{array}{ll}+ & - \\
4 & 1 \\
\end{array}$ & $\begin{array}{ll}+ & - \\
2 & 1 \\
\end{array}$ \\
\hline & & sculin & - & 一 & 一 & - & - & - & - & + & 一 & - & - & 一 & + & - & - \\
\hline \multicolumn{3}{|c|}{ Test strains 158} & 5 & 3 & 2 & 36 & 12 & 5 & 4 & 33 & 14 & 6 & 12 & 10 & 8 & 5 & 3 \\
\hline \multicolumn{3}{|c|}{ Control strain 1} & 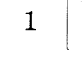 & & & & & & & & & & & & & & \\
\hline
\end{tabular}

Type II. Bacteria of this type remain $\beta$-hemolytic constantly both on the blood of horse, goat or sheep and the addition of glucose.

Type III. Bacteria of this type prove themselves to be perfect $\beta$-hemolytic on the blood taken from the horse, whereas they show the property of $\alpha$-hemolytic on the blood of the goat or sheep. 
TABLE 7

Ando's Classification by Hemolysis of Streptococci on Equi Blood Agar

\begin{tabular}{|c|c|c|c|}
\hline \multirow{2}{*}{ Classification } & \multirow{2}{*}{$\beta$ at type } & \multicolumn{2}{|c|}{$\beta$ at. type } \\
\hline & & $\beta \mathrm{m}$ type & $\beta \mathrm{g}$ type \\
\hline $\begin{array}{l}\text { Diameter of hemolysis } \\
\text { zone in } \mathrm{mm}\end{array}$ & $2.0-4.0$ & $1.9>$ & $4.0<$ \\
\hline Strains 67 & 10 & 57 & 0 \\
\hline $\begin{array}{c}\text { Contrast: } \\
\text { pyogenes } 1\end{array}$ & 1 & & \\
\hline
\end{tabular}

As this classification of KOBAYASHI enables one to detect hemolytic streptococci of Type 1 from the disease foci where the detection of either Type II of Type III is very rare, this is in use rather extensively in Japan as an expedient means of determining the pathogenicity of bacteria derivable from human bodies. Therefore, our hemolytic streptococci were subjected to the hemolysis test per KoBAYASHI's classification. See Table 8.

TABLE 8

Kobayashi's Classification of Hemolytic Streptococci

\begin{tabular}{|c|c|c|c|c|c|}
\hline \multicolumn{3}{|c|}{ Classification } & I Type & II Type & III Type \\
\hline \multirow{2}{*}{ Blood agar } & Equi blood & $\begin{array}{l}\text { Glucose - } \\
\text { Glucose + }\end{array}$ & $\begin{array}{l}\text { Hemolysis } \\
\text { Green }\end{array}$ & $\begin{array}{l}\text { Hemolysis } \\
\text { Hemolysis }\end{array}$ & $\begin{array}{l}\text { Hemolysis } \\
\text { Hemolysis }\end{array}$ \\
\hline & Sheep blood & $\begin{array}{l}\text { Glucose - } \\
\text { Glucose + }\end{array}$ & $\begin{array}{l}\text { Hemolysis } \\
\text { Green }\end{array}$ & $\begin{array}{l}\text { Hemolysis } \\
\text { Hemolysis }\end{array}$ & $\begin{array}{l}\text { Green } \\
\text { Green }\end{array}$ \\
\hline \multicolumn{3}{|c|}{$\begin{array}{l}\text { Str. hemolytic of oral abscess } \\
67 \text { strains }\end{array}$} & 67 & 0 & 0 \\
\hline \multicolumn{3}{|c|}{$\begin{array}{c}\text { Contrast: human str. pyogenes } \\
1 \text { strains }\end{array}$} & 1 & 0 & 0 \\
\hline & $\begin{array}{l}\text { I Type } \cdots \text { La } \\
\text { II Type } \cdots \\
\text { III Type } \cdots\end{array}$ & $\begin{array}{ll}\text { cefield } & \text { group } \\
\prime \prime & \mathrm{B}, \mathrm{C}, \\
\prime \prime & \mathrm{D}\end{array}$ & & & \\
\hline
\end{tabular}

\section{Experiment IV: Benzidine Reaction Test}

Previously, we have confirmed as a result of the benzidine reaction test that viridans streptococci have the property of generating hydrogen peroxide as a metabolic product. Confirmation of the benzidine reaction was attempted on all of the strains under discussion.

\section{Test strains.}

A total bacteria of 133 strains (the breakdown being 67 strains of hemolytic streptococci, 65 strains of viridans streptococci and 1 control strain of LANCEFIELD A Group streptococci pyogenes) were subjected to the prescribed test. Hemolytic streptococci included both $\beta \mathrm{t}$ and $\beta \mathrm{m}$ types.

\section{Benzidine reaction media.}

Table 9 gives the composition of culture media used in conjunction with the prescribed test. 
TABLE 9

Culture Media of Benzidine Reaction

1. Basic media

\begin{tabular}{lc} 
Glucose & $0.5 \mathrm{~g}$ \\
Peptone & 20.0 \\
$\mathrm{NaCl}$ & 5.0 \\
Agar & 30.0 \\
Ag. dest. & $1000.0 \mathrm{cc}$ \\
& \\
\hline
\end{tabular}

The following 2), 3) and 4) are added per $15 \mathrm{cc}$ of basic media
2. $0.3 \%$ benzidine
(Heat treatment)
$2.0 \mathrm{cc}$
3. Poteto juice
(Filter according to Seitz. Not to be diluted)
$0.3 \mathrm{cc}$
4. Serum
$0.1 \mathrm{cc}$

\section{Experimental result.}

Table 10 gives a series of results obtained by the prescribed test. After a 48-hour incubation, 57 strains of hemolytic streptococci (both $\alpha$ and $\beta \mathrm{m}$ types) showed positive, while 10 strains of $\beta \mathrm{t}$ type hemolytic streptococci as well as 1 control strain showed themselves negative.

TABLE 10

Benzidine Reaction of Isolated Streptococci from Oral Abscess

\begin{tabular}{c|c|c|c}
\hline \multirow{2}{*}{ Experiment strains } & \multicolumn{2}{|c|}{$\begin{array}{c}\text { Change of benzidine reaction } \\
\text { nutrient media }\end{array}$} & $\begin{array}{c}\text { Number of reaction } \\
\text { strain }\end{array}$ \\
\cline { 2 - 3 } & 24 hours & 48 hours & 39 \\
\hline $\begin{array}{c}\text { Str. viridans } \\
65 \text { strains }\end{array}$ & + & + & 26 \\
\hline $\begin{array}{c}\text { Str. hemolytic } \\
67 \text { strains }\end{array}$ & - & + & 57 \\
\hline Contrast: Str. pyogenes & - & - & 10 \\
1 strain & - & - & 1
\end{tabular}

\section{Experiment V: Serological Characteristics of Hemolytic Streptococci}

Since the days of LANCEFIELD, studies regarding serological characteristics of hemolytic streptococci have made strides. LANCEFIELD who blazed the path into this domain of research classified hemolytic streptococci into the numeral groups of A-H and $\mathrm{K}-\mathrm{N}$ in terms of precipitation reaction with the use of somatic polysaccharide series, designating as $\mathrm{C}$ substance some polysaccharides which play the factor part in the reaction. Based on his classificatory method, there are known three groups of A, B and C. Therefore, the present hemolytic streptococci isolated from the oral suppurative foci were subjected to the same precipitation test with the use of somatic polysaccharides.

1. Precipitation of immune serums and corresponding strains.

Table 11 and 12 give the experimental results in which the antigens were reacted 
TABLE 11

Precipitation Reaction of Immune Serum and Its Strain

\begin{tabular}{|c|c|c|c|c|c|c|c|c|c|c|}
\hline \multirow{2}{*}{\multicolumn{2}{|c|}{$\frac{\text { Type of str. hemolytic }}{\text { Antigen (number of strain) }}$}} & \multicolumn{6}{|c|}{$\beta \mathrm{m}$ type of $\beta$ at type } & \multicolumn{3}{|c|}{$\beta$ t type } \\
\hline & & 87 & 108 & 111 & 118 & 88 & 110 & 105 & 107 & 97 \\
\hline \multirow{9}{*}{$\begin{array}{l}\text { Immune serum } \\
\text { (number of strain) }\end{array}$} & 87 & $\mathrm{HH}$ & $\mathrm{tHt}$ & $\mathrm{HH}$ & $H$ & $\mathrm{HH}$ & $\mathrm{HH}$ & - & - & - \\
\hline & 108 & $\mathrm{HH}$ & $\mathrm{HH}$ & $\mathrm{HH}$ & Ht & $\mathrm{HH}$ & $\mathrm{HH}$ & - & - & - \\
\hline & 111 & $\mathrm{HH}$ & HH & $\mathrm{HH}$ & tt & $\mathrm{HH}$ & $\mathrm{HH}$ & - & - & - \\
\hline & 118 & $\mathrm{HH}$ & $\mathrm{HH}$ & $\mathrm{tHt}$ & tt & $\mathrm{HH}$ & $\mathrm{HH}$ & - & - & - \\
\hline & 88 & $\mathrm{HH}$ & + & $\mathrm{HH}$ & H & $\mathrm{Ht}$ & $\mathrm{Ht}$ & - & - & - \\
\hline & 110 & $\mathrm{HH}$ & + & $\mathrm{HH}$ & H & $\mathrm{HH}$ & $\mathrm{HH}$ & - & - & - \\
\hline & 105 & - & - & - & - & - & - & $\mathrm{HH}$ & tt & tt \\
\hline & 107 & - & - & - & - & - & - & tt & $\mathrm{HH}$ & tt \\
\hline & 97 & - & - & - & - & - & - & $\mathrm{HH}$ & $H$ & $H$ \\
\hline
\end{tabular}

against the immune serums. As is known from these, it is definitely established that these two series of bacteria have some peculiarity toward their antigenicity (Table 13).

2. Precipitation in terms of serum of LANCEFIELD hemolytic streptococci.

$\mathrm{A}, \mathrm{B}, \mathrm{C}, \mathrm{D}$ and $\mathrm{F}$ normal serums of LANCEFIELD hemolytic streptococci (which were obtained from KITAZATO Bacteriological Laboratory, Tokyo) were used for the precipitation test on these bacteria derived from the oral cavity.

As is known from Table 13, 6 strains of $\beta$ t type show a reaction to A group normal serum, being negative to either of the rest. On the other hand, the majority of $\beta \mathrm{m}$ type bacteria show no reaction to any of these five series of serums used.

\section{Summary and Considerations}

The result of a series of experiments described in the foregoing lines has turned out contrary to the original expectations in that the majority of bacteria detected were streptococci (25 cases out of 40 tested). Those of hemolytic nature are 16 out of 25 cases detected, the rest being mixed cases of hemolytic and viridans (Reference is to Table 1).

The cases of viridans streptococci and non-hemolytic streptococci are 3 respectively (Reference is to Table 2). This may be ascribed to the fact that oral flora have been contaminated with some other bacteria or the use of antibiotics prior to the examination of the patients has caused streptococci hemolytic to disappear. 2 cases of obligate anerobic bacteria, veillonella, have been also detected. An inquiry into possible relationship between the kind of bacteria and diseases has revealed the finding that no particular relationship exists between the two (Reference is to Table 3).

The sensibility test of the bacteria to various antibiotics in common use has revealed the cases in which the antibiotics used are not proper (Reference is to Table 4). The conclusion from this test seems to be that viridans streptococci possess the highest fastness against antibiotics. However, it is doubtful whether the fastness of streptococci viridans and hemolytic is the property attributable to the oral flora or they are the bacteria of antibiotic-fast strain. Most isolated bacteria have shown high sensibility 
TABLE 12

Precipitation Reaction of Str. Hemolytic $\beta \mathrm{m}$ Type

\begin{tabular}{|c|c|c|c|c|c|c|c|}
\hline \multirow{2}{*}{\multicolumn{2}{|c|}{ Antigen }} & \multicolumn{6}{|c|}{ Immune serum (number of strain) } \\
\hline & & \multirow{4}{*}{$\begin{array}{l}87 \\
- \\
- \\
-\end{array}$} & \multirow{4}{*}{$\begin{array}{l}88 \\
- \\
- \\
-\end{array}$} & \multirow{4}{*}{$\begin{array}{c}108 \\
- \\
- \\
-\end{array}$} & \multirow{4}{*}{$\begin{array}{l}110 \\
- \\
- \\
-\end{array}$} & \multirow{4}{*}{$\begin{array}{l}111 \\
- \\
-\end{array}$} & \multirow{4}{*}{$\begin{array}{c}118 \\
- \\
- \\
-\end{array}$} \\
\hline & 97 & & & & & & \\
\hline$+\stackrel{0}{0}$ & 105 & & & & & & \\
\hline & 107 & & & & & & \\
\hline \multirow{30}{*}{ 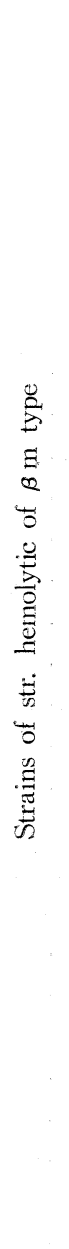 } & 85 & $\mathrm{HH}$ & $H$ & $\mathrm{HH}$ & $H$ & $\mathrm{HH}$ & H \\
\hline & 86 & $\mathrm{HH}$ & $H$ & $\mathrm{HH}$ & $\mathrm{HH}$ & HH & HH \\
\hline & 87 & $\mathrm{HH}$ & $\mathrm{HH}$ & $\mathrm{HH}$ & tH & $\mathrm{HHt}$ & H \\
\hline & 88 & $\mathrm{HH}$ & $\mathrm{HH}$ & + & $\mathrm{HH}$ & HH & H \\
\hline & 89 & HH & $\mathrm{HH}$ & $\mathrm{HH}$ & $\mathrm{HH}$ & $\mathrm{HH}$ & tt \\
\hline & 90 & HH & $\mathrm{HH}$ & tHt & HH & $\mathrm{HH}$ & tt \\
\hline & 91 & $\mathrm{HH}$ & Ht & tHt & tHt & H & H \\
\hline & 92 & $\mathrm{HH}$ & $\mathrm{HH}$ & $\mathrm{HH}$ & $\mathrm{Ht}$ & $\mathrm{Ht}$ & tt \\
\hline & 94 & $\mathrm{HH}$ & $\mathrm{HH}$ & $\mathrm{HH}$ & $\mathrm{HH}$ & Ht & Ht \\
\hline & 95 & $\mathrm{HH}$ & $\mathrm{HH}$ & $\mathrm{HHt}$ & HH & HH & H \\
\hline & 108 & Ht & $\mathrm{tH}$ & H & tH & tHt & H \\
\hline & 109 & HH & HH & $t+t$ & $H$ & itt & H \\
\hline & 110 & $\mathrm{itt}$ & HH & + & HH & HH & tt \\
\hline & 111 & $\mathrm{HH}$ & tH & $\mathrm{Htt}$ & $\mathrm{HH}$ & tH & t+ \\
\hline & 113 & $H H$ & $\mathrm{HH}$ & $\mathrm{tH}$ & $\mathrm{Htt}$ & $\mathrm{HH}$ & H \\
\hline & 114 & $\mathrm{HH}$ & $\mathrm{HH}$ & tH & H & tH & H \\
\hline & 117 & $\mathrm{HH}$ & $\mathrm{HH}$ & $\mathrm{HH}$ & itt & HH & tt \\
\hline & 120 & $\mathrm{HH}$ & $\mathrm{HH}$ & $\mathrm{HH}$ & $\mathrm{tH}$ & tHt & H \\
\hline & 121 & $\mathrm{HH}$ & $\mathrm{HH}$ & $\mathrm{HH}$ & $\mathrm{HH}$ & $\mathrm{HH}$ & t+ \\
\hline & 122 & $\mathrm{HH}$ & H & $\mathrm{HH}$ & $\mathrm{HH}$ & $\mathrm{Htt}$ & t+ \\
\hline & 125 & $\mathrm{HH}$ & $\mathrm{HH}$ & HH & HH & $\mathrm{HH}$ & Ht \\
\hline & 126 & $\mathrm{HH}$ & $\mathrm{HH}$ & $\mathrm{HH}$ & $\mathrm{Ht}$ & $\mathrm{HH}$ & $H$ \\
\hline & 128 & $\mathrm{HH}$ & $\mathrm{HH}$ & $\mathrm{HH}$ & $\mathrm{HH}$ & $\mathrm{HH}$ & t+ \\
\hline & 130 & $H$ & $\mathrm{HH}$ & $\mathrm{HH}$ & $\mathrm{HHt}$ & $\mathrm{HH}$ & H \\
\hline & 131 & $H$ & $\mathrm{HH}$ & $\mathrm{HH}$ & $\mathrm{HH}$ & $\mathrm{HH}$ & Ht \\
\hline & 133 & $\mathrm{HH}$ & $\mathrm{HH}$ & HH & $\mathrm{HH}$ & $\mathrm{HH}$ & H \\
\hline & 134 & $\mathrm{HH}$ & $\mathrm{HH}$ & $\mathrm{HH}$ & $\mathrm{HHt}$ & HH & Ht \\
\hline & 137 & $\mathrm{HH}$ & $\mathrm{HH}$ & $\mathrm{HH}$ & $\mathrm{HH}$ & $\mathrm{tH}$ & $H$ \\
\hline & 141 & $\mathrm{HH}$ & $\mathrm{HH}$ & $\mathrm{HH}$ & $\mathrm{tHt}$ & $\mathrm{tHt}$ & $H$ \\
\hline & 142 & $H H$ & $\mathrm{HH}$ & $\mathrm{HH}$ & $\mathrm{HH}$ & HH & H \\
\hline
\end{tabular}

to such antibiotics as penicillin and aureomycin. As erythromycin has a wide bactericidal spectrum, it may be supposed that this drug has high curative virtue.

Streptococci hemolytic which were obtained differed greatly from common streptococci pyogenes. In terms of colonies, they are found different from $\beta \mathrm{m}$ type designated by ANDO and are rather similar to hemolytic streptococci of small colony designated by 
TABLE 13

Serological Groups of Hemolytic Streptococci by Lancefield

\begin{tabular}{|c|c|c|c|c|c|c|}
\hline \multicolumn{2}{|c|}{ Atigen } & $\mathrm{A}$ & $\mathrm{B}$ & $\mathrm{C}$ & $\mathrm{D}$ & $\mathrm{F}$ \\
\hline \multirow{6}{*}{$\beta$ t type } & 107 & H & - & - & - & - \\
\hline & 105 & tt & - & - & - & - \\
\hline & 104 & $H$ & - & - & - & - \\
\hline & 101 & + & - & - & - & - \\
\hline & 98 & + & - & - & - & - \\
\hline & 97 & + & - & - & - & - \\
\hline \multirow{30}{*}{$\boldsymbol{\beta} \mathrm{m}$ type } & 85 & - & - & - & - & - \\
\hline & 86 & - & - & - & - & - \\
\hline & 87 & - & - & - & - & - \\
\hline & 88 & - & - & - & - & - \\
\hline & 89 & - & - & - & - & - \\
\hline & 90 & - & - & - & - & - \\
\hline & 91 & - & - & - & - & - \\
\hline & 92 & - & - & - & - & - \\
\hline & 94 & - & - & - & - & - \\
\hline & 95 & - & - & - & - & - \\
\hline & 108 & - & - & - & - & - \\
\hline & 109 & - & - & - & - & - \\
\hline & 110 & - & - & - & - & - \\
\hline & 111 & - & - & - & - & - \\
\hline & 113 & - & - & - & - & - \\
\hline & 114 & - & - & - & - & - \\
\hline & 127 & - & - & - & - & - \\
\hline & 120 & - & - & - & - & - \\
\hline & 121 & - & - & - & - & - \\
\hline & 122 & - & - & - & - & - \\
\hline & 125 & - & - & - & - & - \\
\hline & 126 & - & - & - & - & - \\
\hline & 138 & - & - & - & - & - \\
\hline & 130 & - & - & - & - & - \\
\hline & 131 & - & - & - & - & - \\
\hline & 133 & - & - & - & - & - \\
\hline & 134 & - & - & - & - & - \\
\hline & 137 & - & - & - & - & - \\
\hline & 141 & - & - & - & - & - \\
\hline & 142 & - & - & - & - & - \\
\hline Contrast : & T58 & + & - & - & - & - \\
\hline group A & 116 & + & - & - & - & - \\
\hline
\end{tabular}


SHIRATSUCHI and HASEGAWA or to minute hemolytic streptococci of LONG and Bliss. The former has shown Type II of KoBAYASHI classification and, on the other hand, bacteria detected under the present investigation have proved themselves to be Type I with high pathogenicity. They have shown no changes as results of the FORTNER method and anerobic culture, retaining the character of $\beta \mathrm{m}$ type. These findings point to a conclusion that they are bacteria of different strain.

Serological test on streptococci has revealed the fact that those having the strongest pathogenicity on human bcdies are A Group bacteria of LANCEFIELD. They are identified with Type 1 bacteria of KOBAYASHI. Our hemolytic streptococci were subjected to immune-serum of LANCEFIELD A, B, C, D and E types. As a result, whereas the common streptococci pyogenes showed the positive precipitation reaction, our hemolytic streptococci have appeared to be negative to any anti-serum of $\mathrm{A}, \mathrm{B}, \mathrm{C}, \mathrm{D}$ and $\mathrm{F}$ groups (Reference is to Table 13).

It may be considered that these hemolytic streptococci are entirely different from minute hemolytic streptococci of LoNG and BLiss. For they belong to $\mathrm{F}$ and G Groups of LANCEFIELD, while our hemolytic streptococci do not show any reaction with regard to $\mathrm{F}$ Group. However, it is necessary for these bacteria to be tested against all the normal immune-serums of LANCEFIELD before we are justified to establish an independent class for them. At any rate, it is an interesting discovery that a kind of bacteria which have never been found reported from any part of the human body should be found from acute suppurative disease focus in the oral cavity. It is rational to suppose that the fact that streptococci viridans and hemolytic have been mixedly detected from the disease focus is due to the mixed contagion of the two.

9 cases where no hemolytic streptococci have been found deserve our special attention. It is open to question whether they are due to acute infection or the use of antibiotics has caused them to disappear at the time of our investigation. A case of acute endocarditis caused by viridans streptococci and another case of acute suppurative arthritis in small animals attributable to the same pathogenicity are already known. Also the variability of streptococci hemolytic into streptococci viridans is reported.

As the fact that visidans streptococci generate hydrogen peroxide has been determined by SHIRATSUCHI and IKEDA of our Department, these bacteria were examined in this light. As a result, they have clearly shown positive to benzidine reaction after 48 hours (Reference is to Table 10). Also most of viridans streptococci isolated from the disease focus are found to be positive to benzidine reaction after 24 hours. On the contrary, those of streptococci pyogenes are found to be negative to the same test. This fact should furnish us with a clue that these two sets of bacteria have the generative faculty of hydrogen peroxide and one may have turned into the other.

On the other hand, another interesting fact is established that some streptococci viridans form themselves into a form which shows a peculiar precipitation reaction in the hydrocarbon antigen test. Only bacteria that show a peculiar precipitation reaction among viridans species are ' $\mathrm{SBE}$ ' of endocarditis origin, which allows an inference that these 'SBE' have varied themselves. However, in view of the finding by SHIRATSUCHI that when viridans enterococci varied into hemolytic enterococci he obtained a certain peculiar antigen different from the original strains (which correspond to LANCEFIELD D Group), it could be imagined that the present case is a variability of viridans streptococci to hemolytic streptococci. The problem of this variability leaves much field yet to be explored in the future. Researches in this field will no doubt contribute toward better 
elucidation of the pathogenic process of oral suppurative diseases.

\section{Conclusions}

A series of bacteriological tests on the pathogenic foci of oral suppurative diseases has gained the following set of findings:

1. Detection of bacteria.

a. Of 40 examinees subjected to the inquiry, 31 cases are found to detect some kind of bacteria or another with the rate of $77.5 \%$, with 9 cases yielding no result.

b. Breakdown of bacteria detected.

(i) Streptococci occupy the highest percentage with $62.5 \%$ (25 cases). Further, 16 cases are hemolytic streptococci out of which 6 cases are obtained as a result of pure culture, with the remaining 10 being mixed cases of viridans and hemolytic streptococci.

(ii) Only 3 cases are found in which only viridans streptococci are detected. 2 are mixed cases of viridans and hemolytic streptococci and there are 3 cases in which nonhemolytic streptococci are discovered.

(iii) 2 cases are found in which there exist veillonella as anerobic bacteria.

II. There is found no particular relationship between the kind of acute suppurative diseases in the oral cavity and bacteria detected.

III. A result of sensibility test to antibiotics indicates that streptococci have the strongest sensibility to chloromycetin and both aureomycin and penicillin appear to be low. In some cases erythromycin is found to exert very strong effect.

$I V$. Of the detected streptococci which are of hemolytic character, 2 cases (10 strains) are found to be streptococci pyogenes and the remaining 14 cases ( 57 strains) are established as belonging to the class of minute hemolytic streptococci in terms of the size of a hemolytic ring. According to KOBAYASHI's classification based on the hemolysis phenomenon, they are identified to be the bacteria of Group I.

$V$. Bacteria of this specimen are of such a nature that they develop the colonies with a hemolytic ring of small radius ranging from $1.0 \mathrm{~mm}$ to $1.5 \mathrm{~mm}$ after the medium cultivation anywhere from 24 to 48 hours.

$V I$. Characteristics of these hemolytic streptococci in the light of serological investigation in terms of LANCEFIELD method are given as follows:

$a$. Streptococci pyogenes of $\beta \mathrm{t}$ type strain are of A Group.

$b$. An independent class may be assigned with enough justification to $\beta \mathrm{m}$ strain bacteria of $\beta$ at type, as they have shown no precipitation reaction with regard to any of $\mathrm{A}, \mathrm{B}, \mathrm{C}, \mathrm{D}$ and $\mathrm{F}$ Groups.

VII. A benzidine reaction test has proved the oxygen producing property of hemolytic streptococci of $\beta \mathrm{m}$ type. Consequently, it may be inferred that viridans streptococci have varied themselves into hemolytic streptococci.

\section{References}

1) Sherman, J. M. : J. Bact., 1, 3 (1939).

2) Sherman, J. M., Niven, C. F. Jr. and Smiley, K. L. : J. Bact., 45, 249 (1943).

3) Dubos, R. J. : Bacterial and Mycotic Infection of Man.

4) ANDO, K. : Saikin-Gaku Zasshi, 327, 767-791 (1922).

5) Kobayashi, R. : Jap. J. of Contagious Diseases Soc., 3, 97 (1927).

6) Shiratsuchi, J. and Ikeda, T. : Proceedings of 31st Jap. Bact. Soc. Congress (1953).

7) Lancefield, R. C. : J. Exp. Med., 47, 91, 481 (1928). 
8) LANCEField, J. Exp. Med., 57, 571 (1933).

9) Long, P. H. and Bliss, E. E. : J. Exp. Med., 60, 619 (1934).

10) Shiratsuchi, J. and Hasegawa, S. : Saikin-Gaku Zasshi, 483, 299, (1936).

11) Shirtsuchi, J. : Saikin-Gaku Zasshi, 266, 896 (1934).

12) Loewe, L., Plummer, N., Niven, C. F. Jr. and Sherman, J. M. : J. A. M. A. 130, 257 (1946).

13) Shiratsuchi, J., Hirata, J., Ikeda, T.; Haruki, Y. and Kamegaya, Y. : J. of Oral Hygiene, 3, 6, 11 (1953). 